Policy and Information Systems implementation: The Greek Property Tax Information System Case

\author{
Dimosthenis Anagnostopoulos \\ Department of Informatics and Telematics \\ Harokopio University of Athens, Tavros, Greece \\ Email: dimosthe@hua.gr
}

\begin{abstract}
Thanos Papadopoulos
Kent Business School, The University of Kent

Sail and Colour Loft, The Historic Dockyard, Chatham ME4 4TE, UK

Email: a.papadopoulos@kent.ac.uk*
\end{abstract}

Teta Stamati

Department of Informatics and Telecommunications

National and Kapodistrian University of Athens, Greece

Email: teta@di.uoa.gr

\author{
Maria Balta \\ Kent Business School, The University of Kent \\ Canterbury CT2 7FS, UK \\ Email: m.balta@kent.ac.uk
}

*Corresponding author. Tel: +44(0) 1634888494 


\title{
Policy and Information Systems implementation: The Greek Property Tax Information System Case
}

\begin{abstract}
This study contributes to the literature on Information Systems (IS) implementation and provides insights into how IS implementation emerges as an assemblage constituted by diverse sociomaterial practices - that is, the intertwining of humans and technology in practice- during the implementation of Greece's Yearly Property Tax policy and information system over the period 1997-2015. Drawing on the work of Deleuze, Guattari, and Delanda on 'assemblage theory' and Burke's on motive (expressed as 'intentionality' and 'motivation') we discuss IS implementation as a performative process that is shaped by assemblage agents' intentionality and motivation and conclude that explicitly attending to these dynamics during the emergence of policy and technology as a sociomaterial assemblage contributes to a better understanding of IS implementation and its success. We propose that higher levels of motivation and intentionality are related to higher chances of successful implementation. Finally, limitations and future research directions are proposed.
\end{abstract}

Keywords: IS implementation, sociomateriality, assemblage, performative process, intentionality, motivation, Greece.

\section{Introduction}

Countries worldwide are implementing Information Systems (IS) to reform their public sector (e.g. Avgerou and McGrath, 2007; Bloomfield and Hayes, 2009; Ciborra, 2005; Butler and McGovern, 2012; Cordella and Iannacci, 2010; Sadiq et al., 2012; Papazafeiropoulou and Spanaki, 2016).

Reviews of the literature provide different views of how IS is implemented and adopted: firstly, by adopting the functional paradigm (Hirschheim and Klein 1989) and an 'apolitical' stance towards understanding implementation through technology acceptance and diffusion of innovations (Davis, 1989; Rogers, 2003; Venkatesh et al., 2003; Dwivendi et al, 2017; Fosso Wamba et al., 2017; Rana et al., 2017) ; and secondly, discussing IS implementation by underlining the culture and context as complex structures characterised by the interweaving of actors and diverse political, public and private sector agendas (Robey and Markus, 1984; Avgerou et al. 2004; Avgerou and McGrath, 2007; Ciborra 2002; Ciborra and Lanzara 1994; Dang et al., 2017; Introna 1997; Irani et al., 2007; 2008; Walsham, 2001). Finally, the sociomateriality turn in IS “challenges the deeply taken-for-granted assumption that technology, work, and organizations should be conceptualized 
separately and advances the view that there is an inherent inseparability between the technical and the social" (Orlikowski and Scott, 2008). This is either by assuming that "the social and the material are inherently inseparable" (Orlikowski and Scott 2008, p. 456), or by adopting a substantialist ontology that discusses the imbrication of human and material agencies, which are distinct but when mutually interlocked they are effective in achieving outcomes (Leonardi, 2012, 2013; Cecez-Kecmanovic et al., 2014).

Yet, there is dearth of literature discussing the imbrication of human and material agencies during IS implementation from a different perspective, and this gave us the motivation for this paper. Hence, we develop a performative lens to IS implementation based on Deleuze and Guattari (1987), DeLanda (2006; 2011), as well as on Burke's (1969a; 1969b; 2003) motive to introduce intentionality (desire to achieve a goal or a set of goals, referring to the material) and motivation (passion to achieve a goal or set of goals, referring to the social) (Schandorf and Karatzogianni, 2016) as apparatus to study the entanglement of the social and the material and their impact on IS implementation. Our research question is the following: How is IS implementation shaped by the emergence of diverse sociomaterial practices -that is, the intertwining of humans and technology (Orlikowski, 2007)? In answering our research question, we present and discuss a qualitative case study of Greece's Property Tax System from 1997-2015.

The structure of the paper is as follows: In the next section, we offer an overview of the sociomaterial lens to IS implementation. Then we illustrate the perspective deployed in our analysis and its relevance for studying the imbrication of social and material on IS implementation. This is followed by the analysis of our case study. Finally, we discuss the results of this study in light of the literature and provide a summary of our findings, implications on policy and practice, limitations and future research.

\section{Sociomateriality and Information Systems implementation: Deleuze, DeLanda, and}

\section{Burke}

A sociomaterial perspective (Barad, 2003; Leonardi 2011; Leonardi and Barley 2008; Orlikowski and Scott 2008) shifts the focus from how technology influences humans and vice versa to how the 'material' is infused in everyday practices, theorizing the relationship between humans and objects as mutually constitutive and emergent.

From an ontological perspective, sociomateriality follows two schools of thought: the relative school that assumes the inseparable and mutual constitution of the social and the material (Barad, 2003; Orlikowski, 2007; Orlikowski and Scott, 2008); and the substantialist school (Leonardi, 2012, 2013), where human and material agencies are distinct and they have inherent properties, but their 
imbrication and mutual interlocking results in achieving particular outcomes (Cecez-Kecmanovic et al., 2014).

Empirical studies of sociomateriality include, for instance, critical care (Jones, 2014), social media (Scott and Orlikowski, 2014), and the development, introduction and use of a computing grid infrastructure (Venters et al., 2014). The sociomaterial perspective has also been used by Doolin and McLeod (2012) to conceptualise boundary objects (Carlile, 2002; 2004) as sociomaterial assemblages, their performative nature and distributed agency within organizational practices, and the consequences and performances of diverse assemblages over time. Cecez-Kecmanovic et al. (2014) have used a performative perspective to conceptualise IS success and failure as relational effects of sociomaterial actor-networks of developers, managers, technologies, project documents, methodologies and other actors that negotiate objectives, timelines, resources, as well as different agencies of assessment that perform IS assessments.

In this paper, we aim to contribute to the sociomateriality debate by taking an alternative turn in the sociomaterial view of IS implementation drawing on the works of Deleuze and Guattari's (1987) assemblage theory as extended by DeLanda (2006; 2011) and Burke's (1969a; 1969b; 2003) concept of motive.

According to Deleuze and DeLanda, an assemblage refers to an arrangement and grouping of heterogeneous parts, including discursive (e.g. routines, techniques), social (e.g. structures) and material artefacts that relate to each other due to a shared desire to achieve a particular goal. The effect of this shared desire is passion, which is mobilised differently by different assemblages (Schandorf and Karatzogianni, 2016). DeLanda (2006; 2011) has added properties in the assemblage that shift the focus from being human-centred to accommodate also the nonhuman/artefact: firstly, the identity of an assemblage as expressed in the materiality of its parts; and secondly, the definition of an assemblage based on the tendencies and capacities of its parts that define its possibilities of action.

To understand how the assemblage comes into being, we draw on Burke's motives. Schandorf and Karatzogianni (2014) suggest two attributes to define 'motive', that is, 'motivation' and 'intentionality': "motivation is inherently rhetorical and affective, an inevitably embodied, emotional force or capacity grounded in symbolic social identifications, intentionality is a programmatic, even algorithmic, goal-oriented force or tendency characterizing any agent, human or otherwise, pursuing a set of outcomes and having an influence on other agents in its world." Motivation can be affective and may or may not be directly related to reasoned or intended outcomes, whereas intentionality is "defined in relation to a set of goals that may be innate and/or programmed apart from any affective identification with or within a social system. Linking this 
idea to Deleuze and Guattari's passion and desire as defining assemblages, desire is understood as intention and passion as motivation and hence a desire (as intentional force) is an effect of passion (as motivation). Therefore, intention is linked to a "machinic desire" of non-humans and artefacts, whereas motivated human agents within the assemblage manifest "passion".

We use the concepts of intention and motivation in line with Deleuze, Guattari, and DeLanda's theorisation of passion and desire to explain dynamism within assemblages during IS implementation (e.g. how they come into being, how they can be held together and how they can evolve into new assemblages). They can assist us in evaluating whether 'performation' (i.e. the process of performativity) (Yeow and Faraj, 2014) is successful -that is, the assemblage is performing as intended, or further work is required. Hence, performation looks at both how the assemblage changes (e.g. the introduction of an IS) and how the altered or emerging assemblage is performing (ibid).

The concepts of assemblage and performativity have been used in a recent study by Yeow and Faraj (2014). They discussed the emergence of sociomaterial practices after the implementation of IS in two clinics within a hospital, which demonstrated patterns of constituting, counterperforming, calibrating, and stratifying that explained the process of sociomaterial change. Yet, there are studies to explore the emergence of sociomaterial practices during IS implementation, giving us the impetus for this paper and contributing to our deeper understanding of the performativity of sociomaterial assemblages.

\section{Methodology and background of the study}

\subsection{The background of the study}

The Greek case was chosen as the research context of this study. Greece is classified as a developed country. The global debt crisis which burst out in late 2008 and the subsequent public debate regarding the falsification of statistical data of the financial situation of Greece drove up its borrowing costs. In April 2010, Greece was under debt crisis and could no longer borrow from the international markets. Two financial help packages together with strict austerity measures were agreed in 2010 and 2012 to help Greece deal with the consequences of crisis and enable growth. The Greek Government had to undergo substantive reforms aimed at efficiency and good governance, while at the same time increasing tax revenues. To tackle tax evasion, though, is not an easy task. The OECD estimated that in August 2009 the yearly unpaid taxes were around 20B€. Furthermore, Greek Property Taxes are about half the OECD average level of 2.6\% GDP, that is, $1.3 \%$, but are complex so that estate owners may end up paying 14 different types of taxes and levies. While property tax accounts for $0.14 \%$ of the total tax revenue, the collection represents 
$1.1 \%$ of total tax administration costs (OECD, 2009). Therefore, the reform of the property tax system through a national land registry, tax calculation, and tax collection systems will allow property taxation based on the real value of assets. However, as reforms were not accomplished in due time and fiscal targets were not met, a third financial help package (bailout program) was agreed on July 2015.

Key to the enforcement of national property taxation policy is IS/IT, being vital for income generation and decrease in public debt. Here, a controversy-laden IS/IT implementation is described, which lasted for more than fifteen years and still undergoes significant changes in enforcing the taxation policy. The efforts to develop and implement the system were supported by local private partners. We use the nuances and concepts from Deleuze, Guattari, DeLanda, and Burke to unpack these assemblage dynamics that underlie complex IT/IS implementation settings.

\subsection{Data collection and analysis}

This paper adopts a qualitative research approach (Lincoln \& Guba, 1985; Silverman, 2001; Yin, 2003). Primary and secondary data were collected from September 2007 to October 2014 in Greece from relevant stakeholders and institutions related to the IS/IT and taxation national policies and implementation. The interviewees were obtained from related institutions and contexts to get a complete picture of the historical account and experience of the public sector IS/IT and taxation in Greece, and included stakeholders from both the public and private sector. The first author was the project owner from conception until the completion of the phase two, whereas the third author was a project manager in the private sector companies' consortium formed to implement the project.

The data gathered through interviews were recorded and transcribed ad verbatim. They included specific project narratives and stories, which provided detail and insight into the processes of the taxation policy and IS/IT implementation. Eighty (80) semi-structured interviews were conducted, each lasting 60 minutes on average. The interview guide was adapted to the types of interviewees selected and in order to make sure that important areas of the policy and project were covered. The interview questions included three parts: the first part included questions about the necessity of implementing IS/IT to implement property taxation laws, the second part focused on the role of each interviewee per phase of the project, whereas the final part included questions on the role of the IS/IT-enabled taxation in reducing the public debt. Specific questions were targeted to highest echelons governmental stakeholders, e.g. related to the necessity property tax calculation and collection, the use of technology to this purpose, and the changes that took place at the policy level as the system emerged. All the interviews were conducted in Greek in order to enable the 
participants to express themselves in a language that they would communicate without impairment (Bryman and Bell, 2011). In the case where the participants did not agree to be tape-recorded, notes were kept to reflect their opinions. Strict confidentiality regarding the names of participants was applied. Interviews were audio-recorded and transcribed verbatim in Greek. Any notes from the interviews were also recorded in Greek. Important quotes from the interviews and notes were subsequently translated into English ${ }^{1}$.

The events described in the project documents provided a time line on which the interview data was pegged to complete our narrative of the emergence of the IS/IT taxation system and policy. This emergence took place through the interaction particular technologies with top-managers of private IS/IT companies, high-echelon public policy makers, and the ministries of finance and the internal.

The interview transcripts, notes, and project documents were analysed in a twofold way (Nijhia and Merali, 2013). We organised and collated data that resulted in factual description of the events in the project resulting in a chronological account of events and we then analysed these data to reflect, interpret and develop analytical accounts of the emergence of the taxation system and policy.

To organise and analyse our primary data we used NVivo software. We tracked and collated themes, issues, and ideas from the transcript data, and identified key events and developments in the unfolding IS/IT and taxation policies and systems. The analysis was iterative and recursive between data and themes. As more transcripts and documents were added, the emergence of new themes was diminishing until no new themes could be added. To analyse the secondary data, we used a chronological account of the evolution of systems and IS/IT and taxation policy. This served as a skeleton for the interview narratives and analysis in a documented historical line, and was expanded with interview and observation data in the analytical step of our analysis.

We developed an analytical history of the emergence of the system. The taxation system was perceived as a socio-technical assemblage that emerged from the interaction of agents, technology and socio-systemic constraints. The analysis was concerned with changes in taxation and IS/IT and their impact to the taxation system. We built the analysis by comparing and contrasting interview narratives and project documents. Five periods were identified inductively from the data as derivative nodes using NVivo from the chronological account. Each phase was analysed and presented as an analytical history of the emergence of the taxation policy and system.

${ }^{1}$ One of the authors is full-time academic in the United Kingdom. 
Figure 1 extrapolates the detailed timeline of events over the years as both policy and system emerged. Both IS/IT and policy are closely intertwined and were analysed at the same time to provide a holistic picture of the emergence of the system and policy.

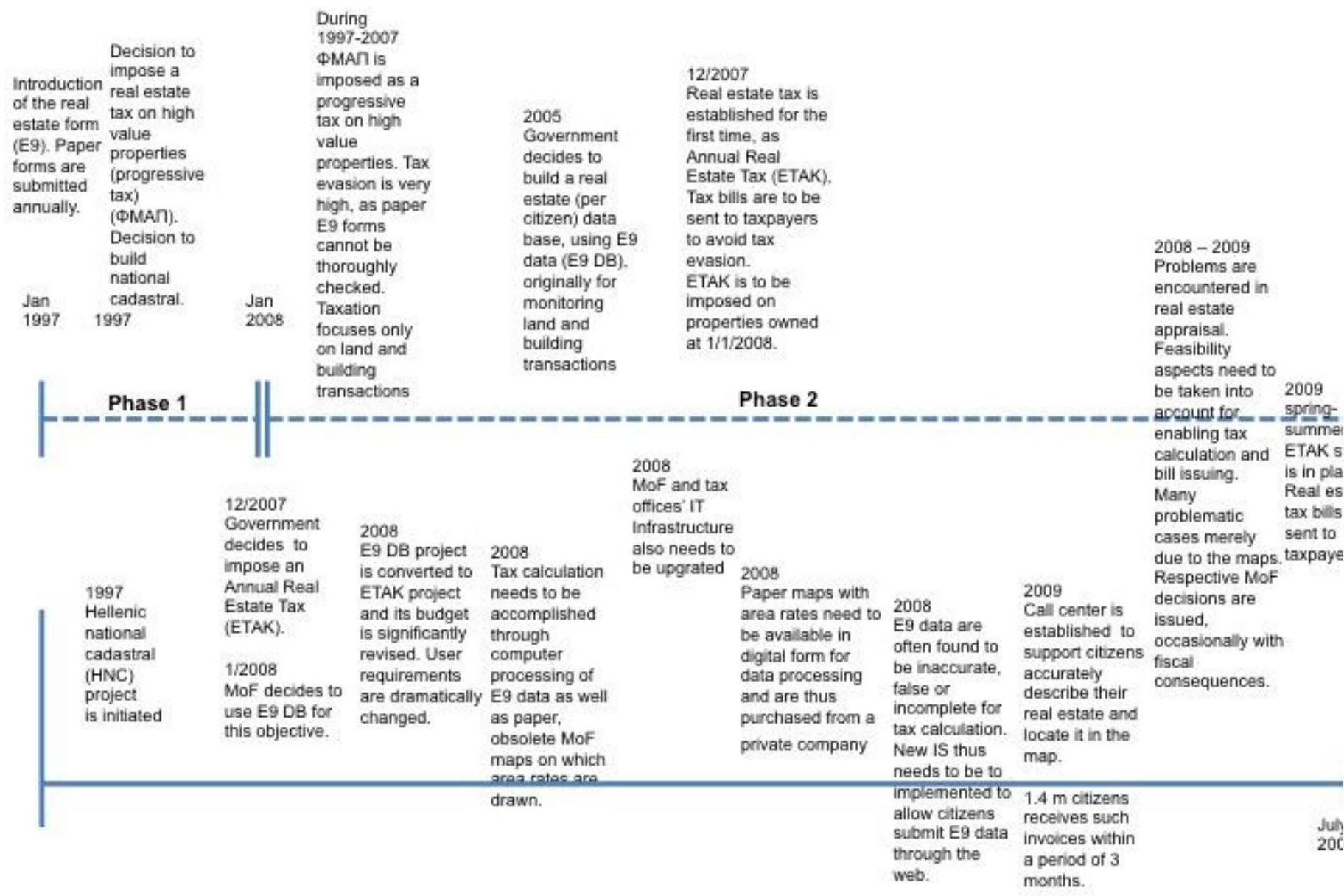




\begin{tabular}{|c|c|c|c|c|c|c|c|c|}
\hline \multirow[t]{2}{*}{$\begin{array}{l}\text { Global Crisis } \\
2008\end{array}$} & $\begin{array}{l}\text { New government } \\
\text { is in power } \\
\text { New prionities are } \\
\text { set } \\
\text { October } 2009\end{array}$ & $\begin{array}{l}\text { Property tax } \\
\text { changes name } \\
\text { and nature } \\
2010\end{array}$ & $\begin{array}{l}\text { Greece is } \\
\text { officially in crisis, } \\
\text { receives 'junk } \\
\text { bond status' } \\
2010\end{array}$ & $\begin{array}{l}\text { Memorandum I } \\
\text { is signed. } \\
\text { Austerity } \\
\text { measures are } \\
\text { taken } \\
2010 \\
\text { Phase } 3\end{array}$ & $\begin{array}{l}\text { As property tax } \\
\text { cannot be } \\
\text { collected through } \\
\text { ETAK system, an } \\
\text { additional tax } \\
\text { EETHAE (Harac) } \\
\text { is enforced for } \\
\text { fiscal reasons. } \\
\text { This additional tax } \\
\text { causes severe } \\
\text { protests from } \\
\text { citizens. } \\
2011\end{array}$ & $\begin{array}{l}\text { The PM } \\
\text { resigns. } \\
\text { Government } \\
\text { of national } \\
\text { unity is } \\
\text { formed. }\end{array}$ & $\begin{array}{l}\text { The Greek } \\
\text { parliament } \\
\text { passes } \\
\text { Memorandum } \\
\text { II } \\
2012\end{array}$ & $\begin{array}{l}\text { Snap e } \\
\text { takes p } \\
\text { party s } \\
\text { clear y } \\
\text { 'GREX } \\
\text { not exc } \\
2012\end{array}$ \\
\hline & $\begin{array}{l}\text { Attempt to redesign } \\
\text { the whole ETAK } \\
\text { system and process } \\
\text { and use Google maps } \\
\text { instead of MoF } \\
\text { manual maps, } \\
\text { digitized by a private } \\
\text { company. } \\
\text { Not implemented } \\
\text { eventually, as this } \\
\text { cannot be easily } \\
\text { accomplished. } \\
\text { Valuable time is lost. } \\
2010\end{array}$ & $\begin{array}{l}\text { Property tax } \\
\text { name chan } \\
\text { (ФAП). } \\
\text { Tax rates ar } \\
\text { algorithms } \\
\text { not severely } \\
\text { altered } \\
2010\end{array}$ & $\begin{array}{l}\text { Fiscal goals } \\
\text { tax revenues } \\
\text { achieved as } \\
\text { system is no } \\
\text { Attempts to } \\
\text { system throu } \\
\text { outsourcing } \\
\text { house devel, } \\
2011\end{array}$ & $\begin{array}{l}\text { on property } \\
\text { s cannot be } \\
\text { ETAK } \\
\text { t updated. } \\
\text { update } \\
\text { ugh } \\
\text { and in- } \\
\text { opment fall. }\end{array}$ & $\begin{array}{l}\text { EETHAE is } \\
\text { imposed or } \\
\text { buildings, } \\
\text { upon floor- } \\
\text { data kept b } \\
\text { electricity c } \\
\text { It is collect } \\
\text { through ele } \\
\text { bills } \\
\text { However, t } \\
\text { annual pro } \\
\text { remains in } \\
2011\end{array}$ & $\begin{array}{l}\text { s } \\
\text { nly on } \\
\text { based } \\
\text {-area } \\
\text { by the } \\
\text { company. } \\
\text { ted } \\
\text { ectricity } \\
\text { the } \\
\text { perty tax } \\
\text { effect. }\end{array}$ & $\begin{array}{l}\text { Propert } \\
\text { years } 20 \\
\text { have no } \\
\text { collecte } \\
\text { fiscal co } \\
\text { This als } \\
\text { the idea } \\
\text { deliverir } \\
\text { agreed. } \\
2012\end{array}$ & $\begin{array}{l}\text { axes for } \\
9 / 2010 / 2 \\
\text { been } \\
\text { with sev } \\
\text { sequenc } \\
\text { adheres } \\
\text { f Greece } \\
\text { What wa }\end{array}$ \\
\hline
\end{tabular}




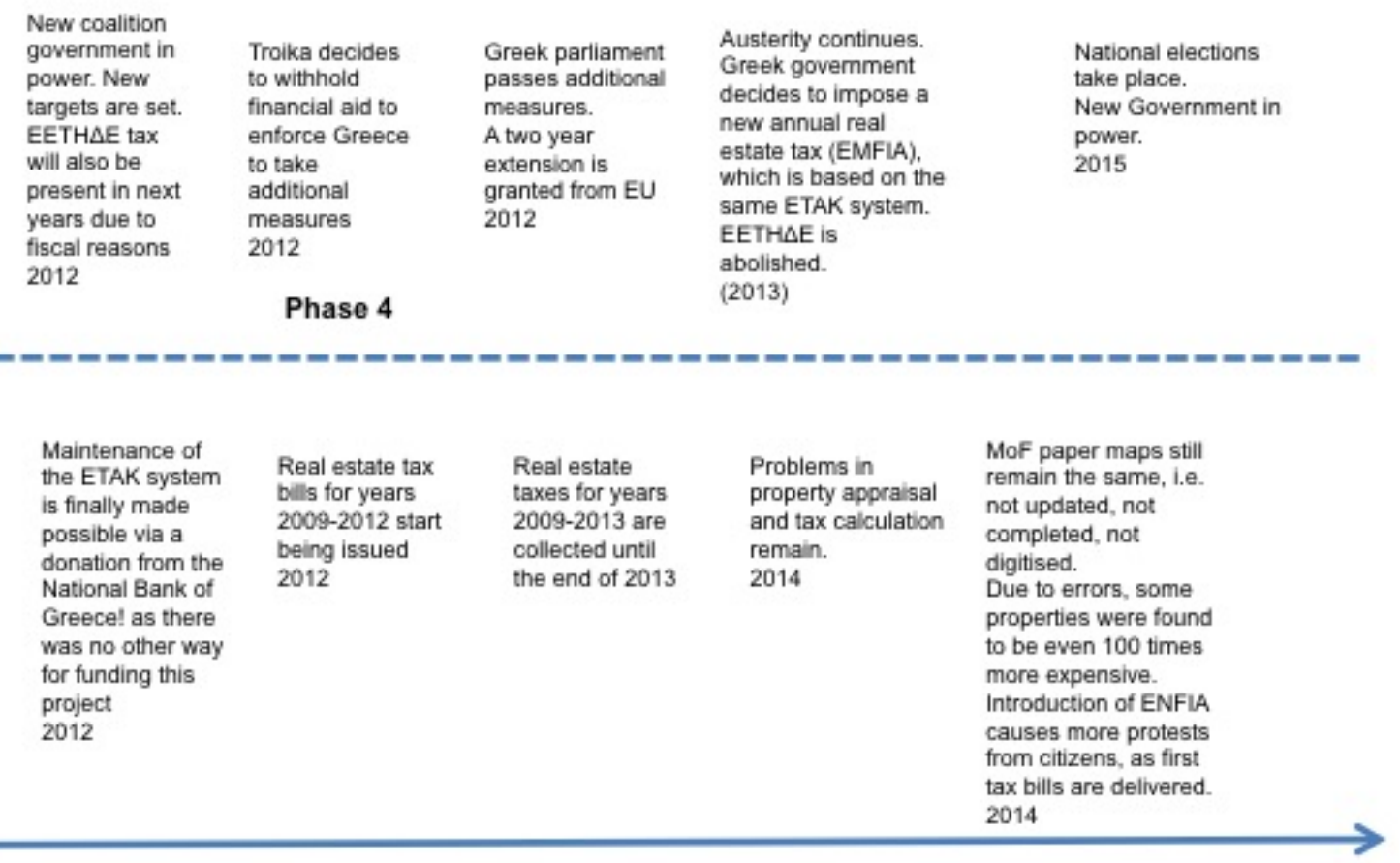

Figure 1: The timeline of events

\section{Case narrative: the Property Tax Information System (ETAK)}

Our case study covers a period of eighteen years, from 1997 to 2015, divided in four phases. It is noted that here is presented a summary of the emergence due to reasons of space and more details are included in Figure 1. However, we reveal the significant mechanisms to the reform of the Greek property taxation using IS/IT. The four phases are described next.

\subsection{Phase I (1997-2008): Initial attempts to establish and enforce a Property Tax and Property Registry}

Greek Governments had been trying to enforce a Property Tax (RET) in numerous occasions. But up to 2008, the Ministry of Finance (MoF) was unable to get substantial revenues through RET, despite attempts by two Governments in the 90s. Legislation on RET had been introduced and abolished three times but tax evasion was high. To enforce such a tax, the State needed a citizen property register, a process for enlisting properties in the register, an IS/IT system to process the data from the property register on the basis of an algorithm for tax calculation and a mechanism for tax collection enforcement, as well as appropriately trained staff. The MoF lacked both the infrastructure and organizational capabilities.

In 1997, a Large Property Tax (in Greek: ФМАП Law 2459/1997) was imposed on high value properties, as a progressive tax. To enforce citizens to declare their property property, MoF also 
introduced the property form (E9). E9 is a paper-based form submitted annually. The tax was calculated depending on the location of the property as well as features such as the area and type of the estate, enlisted by citizens in their E9. However, data were not entered consistently in an information system and were often incomplete or got 'lost' in bureaucracy. As a result, even though this tax only concerned a limited number of citizens, a database (DB) with their properties was not maintained. At that time there was no intention to use the E9 form (e.g. for locating the properties enlisted in E9 form) in order to implement a property tax system.

In 2005, the Government decided to build a property (per citizen) database, using E9 form data (E9 DB), originally for monitoring land and building transactions. To promote e-government across Greece and build up the E9 DB with minimum problems in the quality of data, MoF created and freely distributed a software application that enabled filling the E9 form as a wizard. It was the first time that the E9 form could be electronically submitted, and led to up to 350.000 electronic submissions.

In 2007, deviations from fiscal targets and EU targets occurred and friction in the relationship between Greece and EU started to emerge. An interviewee stated that the inability of the Government to enforce and collect RET was a technological, fiscal, but primarily a political issue:

"This is not only a technological or fiscal matter. It is deeply political since it has to do with the way Greece is evaluated and regarded within the EU, it is a matter which is always discussed in EU Summits. And it is a shame that a matter relating to the taxation of real property of all citizens had not been tackled until today" (High-echelon public employee).

In 2007, the conservatives were in power. Property taxation using IS/IT had been low in the priority list. Any attempts by stakeholders to engage in the development of a new taxation system were dissolved in the political sphere, Stakeholders at the political and project level preserved what was accepted at the time, and did not encourage or favour innovation. This temporal 'stasis' however, was to be changed in Phase II.

\subsection{Phase II (2008-2009): The emergence of ETAK for RET calculation and enforcement}

The remit of the EU to push for changes in the fiscal policy of Greece, triggered by the outburst of the global crisis, necessitated radical changes. The Greek Government sought for solutions to facilitate the execution of the fiscal budget and help the economy recover. To this purpose, the Government decided to reintroduce property tax, namely, "Property Tax" (in Greek: "ETAK"), but, for the first time, aiming to include all properties, in 2008, with the expectation that the 
introduction of a new RET would bring significant revenues. Tax bills were to be sent, also for the first time, directly to taxpayers to avoid tax evasion.

Two possible ways to introduce ETAK emerged: either through the E9 form or electricity bills. The Greek public Electricity Company had a property register, but it was incomplete, often fed with inaccurate data and included only buildings (i.e. properties provided with electricity), excluding land. If ETAK were thus to be collected through electricity bills, an unfair, arbitrary tax would be assigned. Therefore, the only feasible solution was to use the E9 DB as the basis for building the ETAK system. As a consequence, the E9 DB project objectives were drastically modified to serve the ETAK project and its budget was significantly revised. This created challenges regarding the digitalisation, consistency, and validation of the existing E9 data. More importantly, there was no decision at the political level concerning the algorithm for estimating the value of the various property types, not even for the tax calculation algorithm.

Nevertheless, the government decided to use the E9 form while the creation of the property database (E9 DB) was an on-going project. The decision was to create these specifications during the implementation of the system. ETAK was to be calculated as a progressive tax based on the overall appraisal of all family member's properties. For the latter, the E9 attributes were to be used. The direction and user requirements of the project were 'violently' changed:

"The direction did not change from $A$ to $A$ '; it was from $A$ to $C$; this is completely different!" (Project manager)

Decisions on property values, tax rates, and the calculation of the property tax were not taken apriori but during the implementation of the system. The project owner commented:
"After eight months in the implementation of the project governmental decisions provided directives on how property value, tax rate, and tax for each property and for all properties registered in each tax statement were to be calculated. This is really important, because we are talking about a project that is implemented without any established processes for tax collection, nobody knew how properties would be appraised and how the tax would be calculated."

Another high-echelon public employee commented: 
"The policies and regulatory framework came afterwards. The technical project specifications and the project status at a specific time frame determined the regulatory framework. The technology and project progress defined the user requirements a-posteriori based on the logic "what can we do with what we have".

When an algorithm was implemented in the system, it was this algorithm that was then expressed as a political/governmental decision. However, even then, tax calculation was not straightforward, as was determined as a progressive tax based on the overall appraisal of the family members' properties, after excluding the family's residence of the highest value, which was occasionally problematic.

"The regulatory framework - that is, government decisions on the way properties would be appraised, tax rates and tax calculation were like an acrobat walking on a tightrope, and balancing between what was feasible with the current technology/data and what was desirable by the government... this framework, was formed in a bottom up way".

There was strong political pressure and will for rapid project implementation: the EU supported the project since the system would facilitate tax calculation and collection and therefore could help Greece overcome its financial problems. At the project level (IS/IT implementation), there was support from the project team, since it would help the Government collect taxes and therefore deal with the Greek fiscal problem. The plan was for the State to receive property tax income so that the fiscal goals for 2009 would be met as planned. The system was therefore in place within the first semester of 2009 and tax bills were accordingly sent to citizens. ETAK system brought apparent benefits for property tax calculation and enforcement, contributing to the successful execution of the fiscal budget.

However, the global economic crisis burst in late 2008 and this impacted the already fragile Greek economy.

"When the system was in place in 2009, it was the first year when Greece had a buge budget deficit... it was the first year where Greece got its bad reputation... the global economic crisis had also arrived impacting the economy and then the story began... the inclusion of Greece in the support mechanism in the years to come and the arrival of the Troika..." 
Therefore, in Phase II the policy-level regulatory framework was determined by the IS/IT system project and allowed $\mathrm{MoF}$ and Companies $\mathrm{A}$ and $\mathrm{B}$ to design and implement the system, the tax calculation algorithm, and the tax policy. Both the regulatory framework and system were necessitated by the reform-minded actors at the IS implementation level, including the project team (the private sector companies, the implementation team, and project managers from the public sector), and society. The influences of the requirements from EU conditioned these interactions. Large-scale change was possible and necessary to meet the demands of the economy, and this was translated as 'pragmatism'. However, no matter if the system was in place and citizens had received their tax return forms, changes in the political scenery and economy triggered changes in the way the system would be used.

\subsection{Phase III (2009-2012): The start of the Memoranda era}

From Phase II it was apparent that the seamless operation of ETAK depended on two axes: firstly, up-to-date data; and secondly, up-to-date algorithms based on valuation bands for property appraisal and tax calculation. However, a new Government came into power in 2009, bringing changes and new priorities within the MoF. The new Government did not acknowledge at first the criticality of the ETAK system and its maintenance, improvement, and extension. At the political level, they decided to change the property tax law into a 'new' tax, called "Property Tax" (in Greek: "ФАП") that did not have a profound impact on the way the tax would be calculated, except from the tax rates. Furthermore, decisions previously taken regarding the ETAK system were challenged. Focus was: (i) on the way the system had been developed, that is, why E9 digitisation was not performed in-house and was assigned to a contractor; and (ii) why the system did not adopt an open-source platform. Government officials criticised heavily the change in focus:

\footnotetext{
"The fact that you have in Greece politicians who constantly change technological and other priorities already set by the previous Government... there cannot be any continuation in the implementation of large scale IS because the user-requirements constantly change... there is no continuity and no consistency."
}

Attempts to update ETAK through outsourcing and in-house development failed and its maintenance came to a standstill, since (i) at the project (IS/IT implementation) level the alternative of open source was abandoned, and the tax algorithms were not updated; and (ii) at the 
policy level there was limited political will for the maintenance and update of ETAK. When the Government tried to update the system by assigning the project to the same contractors without issuing a call for tender, they failed to convince the legal authorities who were responsible for authorizing this contract. In addition, it failed to ensure the necessary funds from the EU support framework and had to use funds from the state budget.

At that time, rapid political developments took place. In May 2010, Greece entered the debt crisis period and the government called for help and signed a memorandum with the International Monetary Fund (IMF). The deal included, inter alia, cuts in public spending and high taxes in exchange for a $€ 110$ billion bailout. However, despite these attempts, the impact of the global recession and the fact that Greece did not conform to all points of the agreement with the IMF brought a second round of measures and financial aid from the EU, the European Central Bank (ECB), and the IMF, that is, the 'Troika'. A new memorandum (Memorandum II) was signed, which involved a $€ 110 \mathrm{bn}$ loan with stricter austerity measures, privatisation and structural reforms by 2015. Fiscal goals on property taxes cannot be achieved for three consequent years (20092011). Since there was no way to increase state revenues and the ETAK system could not be used as it was obsolete, the Government enforced a new property tax through electricity bills. The tax, called Special Property Tax for Electrified Surfaces (in Greek: EETH $\Delta$ E Law) was nicknamed "Haraç" (from Turkish: Haraç: a poll-tax in the Ottoman Empire). The tax was calculated based on floor-area data, which are maintained by the electricity company, and it was collected through electricity bills. It was expected that the property tax would raise $2 \mathrm{Bn}$ Euros, according to Government calculations. However:
“...the Haras came about, which suggests a tax upon everybody, righteous or not. Everybody is protesting because it is really bigh and unfair and unrighteous... this tax is still into effect since it was introduced three years ago, although it was announced for one year. It is proved that if one cannot do something with the righteous way, he/ she introduces something which is against people who bear all the burdens... the electricity company tax is only on the properties which can have electricity and these are only residences. Land is not included... if somebody has $15.000 \mathrm{~m}^{2}$ land in an expensive area, he / she will not pay a single dime."

In November 2011, the Greek PM asked for a referendum on the EU deal. The reactions were rapid within Greece, and the PM resigned. The European stock-markets dropped around 3-4\%. A Government of national unity was formed to take the country through the Memorandum II, which was finally ratified in February 2012 and activated a month later. In May 2012, national elections 
took place. Since no Government could be formed, a strong speculation ('GRExit') was to affect international markets. The formation of a coalition under the conservative party in June 2012 ended this speculation.

Therefore, in Phase III, the new dynamics within the assemblage concerned the abandonment of the ETAK at the project and policy level, whereas at the policy level the actors were organised in a new constellation, that is, "Government and Troika" to provide new policies (austerity measures and reforms). Citizens were no longer part of the property taxation reform process and were opposed to any austerity measures, no matter if the Government claimed these would get the country out of the crisis. The project and tax policy came to a standstill. However, no matter if ETAK system was or not part of the reform plan and tax policies, it would play an important role in Phase IV.

\subsection{Phase IV (2012-2015): Memorandum II and further challenges to property taxation}

In June 2012, the newly formed coalition Government had to proceed to radical reforms and privatisation. Still, the ETAK system was not used or maintained since 2011 and property tax was based on electricity bills.

Measures of $€ 18.8$ bn were decided by the Government in November 2012 for a two-year extension of the bailout programme and further reduction of the debt. EU made it clear that RET should be reinforced through ETAK as revenues from three consecutive years (2009-2011) had not been collected. A sponsorship from the National Bank of Greece helped revitalising the system:

\footnotetext{
"The system is currently very difficult to be brought up to date...there was no concern regarding an appropriate maintenance. Therefore, new property data were not added, tax rates were not updated, property values could be estimated and thus no tax could be calculated, etc... the result is that the State could not collect the property tax. Previous Governments should have realised the criticality of the project."
}

With the updated ETAK in place, RET bills for years 2009-2012 were issued starting from the summer of 2012. Revenues from RET were collected until the end of 2013.

"If the system was maintained and updated we would have gained around 1.5 million more income per year, and we would look more consistent to our EU partners. Income from RET raised from 487 million in 2010 to almost 3 billion euros at 2012 and 2013, as taxes where aggregately collected. It is not only a fiscal issue, but also one of credibility. In 
political terms we could bave acbieved a better relationship with our partners. In financial terms, some of the measures included in the memorandum could have been avoided... we would then have had a memorandum 'baircut' instead".

In December 2013, the government decided to impose a new annual RET, namely ENFIA (in Greek: ENФIA) to be applied to all types of property, including agriculture estates. The previous tax (i.e. EETIDE) is abolished. The first tax bills were sent in August 2014. Protests from citizens increased as tax bills are delivered, as due to errors in tax calculation, some properties were found to be even 100 times more expensive. This resulted in a serious political issue for the government that became seriously unpopular, and this caused (according to opinion polls) the major defeat of the government at the national elections in 2015.

Phase IV was turbulent. Both the Government and the Troika pushed for reforms. A number of reforms in taxation were to be materialised through the ETAK system. Citizens protested against austerity measures and unfair taxing mechanisms but they had to accept changes to occur through ETAK and property tax reform. There was, however, goodwill by ministers, top servants, and private sector companies that participated in the development of the ETAK system and tax policy. Necessary changes in the taxation policy were conducted, as dictated by the project and were followed by necessary reforms at the policy level. This was observed by the new initiatives at both the policy level (e.g. the request for extension and further help, which were not considered before), the revival of ETAK and the exchange of ideas at the project level (e.g. new policies for taxation of movable and immovable assets through ETAK) that were materialised at the policy level.

\section{Discussion}

\subsection{IS implementation: motivation and intentionality}

In this paper we conceptualised the Greek taxation system as an assemblage that emerges of diverse sociomaterial elements (Table 1). We offer the nuances of intentionality and motivation and illustrate the different aims and goals of each of the actors, as were manifested in each of the phases. In phase I in particular, there was motivation and intentionality of all actors involved to encourage innovation and support the introduction of taxes, although this was later dissolved from the governmental actors within the assemblage. In Phase II however, both intentionality and motivation were high. There was political will from the government and citizens to collaborate in order to battle tax evasion, achieve the fiscal targets and help the economy recover through tax revenues. The two participating companies and the project consortium that was created aimed at successfully implementing the ETAK system. The motivations and intentions of the assemblage 
were homogeneous. This, however, was to change in Phase III, where the different motivations and intentions of the actors constituting the assemblage contributed to its dissolution. Although at a political and project level there were motivated to fight tax evasion and help the Greek economy be strong again, these motivations did not include the use of ETAK, no matter if the benefits have been highlighted and its use was initiated in the previous phase. The Memoranda I and II had highlighted the need for the Greek government to proceed to deep structural changes; but the Government had no plans to maintain and update the system. The motivation of the project consortium was the opposite, but without support it 'collapsed'. Therefore, the motivation and intentionality within the assemblage was low, and disintegration started to occur. In phase IV the coalition government had to proceed to the reforms as per Memorandum II, and improve the state of Greek Economy by, inter alia, collecting tax revenues and the use of system. The property taxes at this stage intended to deal with the aforementioned issues, and therefore intentionality was high for reforms (and the use of the system).

Table 1: Motivation and intentionality for each of Phases I, II, III, and IV.

\begin{tabular}{|c|c|c|c|c|}
\hline & \multicolumn{4}{|c|}{ Project Phases } \\
\hline $\begin{array}{l}\text { Motivation } \\
\text { and } \\
\text { intentionality }\end{array}$ & Phase 1 & Phase 2 & Phase 3 & Phase 4 \\
\hline $\begin{array}{l}\text { Motivation } \\
\text { (Passion) }\end{array}$ & $\begin{array}{l}\text { Human actors: (i) } \\
\text { Greek government } \\
\text { (MoF); (ii) EU. } \\
\\
\text { Motivation: } \\
\text { (i) Introduction of } \\
\text { property tax; } \\
\text { Motivation from } \\
\text { MoF is later } \\
\text { dissolved; } \\
\text { (ii) EU } \\
\text { 'passionate', } \\
\text { encouraging } \\
\text { innovation }\end{array}$ & $\begin{array}{l}\text { Human actors: (i) Greek } \\
\text { government (MoF); (ii) } \\
\text { Citizens (iii) EU; (iv) } \\
\text { Companies A and B } \\
\text { Motivation: } \\
\text { (i) Achievement of fiscal } \\
\text { budget and help the } \\
\text { economy recover through } \\
\text { high tax revenues; } \\
\text { (ii) helping State collect } \\
\text { taxes (providing details of } \\
\text { property } \\
\text { locations/size/value for } \\
\text { tax calculation) } \\
\text { (iii) Changes in the fiscal } \\
\text { policy of Greece, } \\
\text { triggered by the outburst } \\
\text { of the global crisis; } \\
\text { (iii) Successful } \\
\text { implementation of the } \\
\text { ETAK system. }\end{array}$ & $\begin{array}{l}\text { Human actors: (i) } \\
\text { New Greek } \\
\text { government (MoF); } \\
\text { (ii) Citizens (iii) } \\
\text { Project team (incl. } \\
\text { MoF, A and B) (iv) } \\
\text { IMF; (v) Troika (EU, } \\
\text { ECB, IMF); (vi) } \\
\text { Coalition } \\
\text { government } \\
\\
\text { Motivation: } \\
\text { (i) Limited/no } \\
\text { motivation- no } \\
\text { political will to keep } \\
\text { on updating ETAK, } \\
\text { collecting taxes, and } \\
\text { increasing revenues; } \\
\text { (ii) No motivation, } \\
\text { protesting against the } \\
\text { new taxes and } \\
\text { EETH } \Delta \text { E (Harac); } \\
\text { (iii) Update/run } \\
\text { ETAK system, but } \\
\text { hampered by top } \\
\text { level focus on } \\
\text { redesigning the } \\
\text { whole process and }\end{array}$ & $\begin{array}{l}\text { Motivation: } \\
\text { (i) Political will to } \\
\text { proceed to the } \\
\text { reforms as per } \\
\text { Memorandum II, } \\
\text { improve the state } \\
\text { of Greek } \\
\text { Economy. Collect } \\
\text { tax revenues and } \\
\text { bring ETAK back } \\
\text { to use; } \\
\text { (ii) No motivation, } \\
\text { protesting against } \\
\text { the new taxes } \\
\text { (iii) Help revive } \\
\text { ETAK system for } \\
\text { tax calculation and } \\
\text { collection } \\
\text { (iv) Improvement } \\
\text { of Greek }\end{array}$ \\
\hline
\end{tabular}




\begin{tabular}{|c|c|c|c|c|}
\hline & $\begin{array}{l}\text { Motivation is high for } \\
\text { the tax revenues, } \\
\text { although dissolved at } \\
\text { a later stages of this } \\
\text { phase }\end{array}$ & $\begin{array}{l}\text { Motivation is high for the } \\
\text { ETAK system }\end{array}$ & $\begin{array}{l}\text { system, and use of } \\
\text { Open Source; } \\
\text { (iv) Improvement of } \\
\text { Greek } \\
\text { economy/debt via a } \\
€ 110 \text { billion bailout, } \\
\text { but in exchange: } \\
\text { austerity measures } \\
\text { and } \\
\text { structural reforms to } \\
\text { improve growth and } \\
\text { competitiveness; } \\
\text { (v) Improvement of } \\
\text { Greek } \\
\text { economy/debt } \\
\text { through a } € 110 b n \\
\text { loan with stricter } \\
\text { austerity measures, } \\
\text { privatisation and } \\
\text { structural reforms, as } \\
\text { well as a 'debt } \\
\text { haircut' } \\
\text { (vi) Proceed to the } \\
\text { reforms as per } \\
\text { Memorandum II, } \\
\text { improve the state of } \\
\text { Greek Economy. } \\
\text { Motivation is low for the } \\
\text { ETAK system }\end{array}$ & $\begin{array}{l}\text { economy/debt } \\
\text { through new } \\
\text { measures of } \\
€ 18.8 \text { bn in } \\
\text { exchange for a } \\
\text { third bailout loan } \\
\text { of } € 30 \text { bn for a } \\
\text { two-year extension } \\
\text { of the bailout } \\
\text { programme. } \\
\text { Motivation is high for } \\
\text { the ETAK system } \\
\text { (this time imposed } \\
\text { indirectly by the } \\
\text { measures) }\end{array}$ \\
\hline $\begin{array}{l}\text { Intentionality } \\
\text { (Machinic } \\
\text { desire) }\end{array}$ & $\begin{array}{l}\text { Non-human } \\
\text { actors: } \\
\text { technologies } \\
\text { (property register, } \\
\text { HNC, and E9 } \\
\text { form) as well as } \\
\text { policies (Large } \\
\text { Property Tax) } \\
\text { Intentionality: } \\
\text { introduction of } \\
\text { property tax }\end{array}$ & $\begin{array}{l}\text { Non-human actors: (i) } \\
\text { New property tax, that is } \\
\text { ETAK; (ii) E9 form; (iii) } \\
\text { Geographical maps (iv) } \\
\text { Property tax Information } \\
\text { system (ETAK system) } \\
\text { (v) Tax collection policy } \\
\text { as an outcome of the } \\
\text { ETAK system } \\
\text { implementation } \\
\\
\text { Intentionality: } \\
\text { (i) Property tax collection } \\
\text { (i) Property size register } \\
\text { (iii) Property location } \\
\text { (iv) Property value and } \\
\text { tax calculation, } \\
\text { determination of the } \\
\text { regulatory framework and } \\
\text { policy for tax collection } \\
\text { (v) Tax collection, } \\
\text { revenues and fiscal } \\
\text { budget achievement }\end{array}$ & $\begin{array}{l}\text { Non-human actors: } \\
\text { (i) New tax name; (ii) } \\
\text { New project policies: } \\
\text { why not in house, } \\
\text { why not open, google } \\
\text { maps (iii) New } \\
\text { property tax through } \\
\text { electricity bills } \\
\text { (Harac) (iv) } \\
\text { Memorandum I; (v) } \\
\text { Memorandum II } \\
\\
\text { Intentionality: } \\
\text { (i) Different tax rates, } \\
\text { no further changes; } \\
\text { (ii) Focus on project } \\
\text { decisions considered } \\
\text { by previous } \\
\text { government, Open } \\
\text { Source and Google } \\
\text { maps; } \\
\text { (iii) Tax collection, } \\
\text { revenues and fiscal } \\
\text { budget achievement } \\
\text {-abandonment of } \\
\text { ETAK } \\
\text { (iv) and (v): facilitate } \\
\text { reforms, deal with }\end{array}$ & $\begin{array}{l}\text { Non-human } \\
\text { actors: (i) New } \\
\text { property tax; (ii) } \\
\text { Memorandum II } \\
\text { Intentionality: } \\
\text { (i) Tax collection, } \\
\text { revenues and fiscal } \\
\text { budget } \\
\text { achievement } \\
\text { through ETAK } \\
\text { system; } \\
\text { (ii) Facilitate } \\
\text { reforms, deal with } \\
\text { tax evasion, and } \\
\text { structural changes } \\
\text { through ETAK } \\
\text { system. }\end{array}$ \\
\hline
\end{tabular}




\begin{tabular}{|l|l|l|l|l|}
\hline & & $\begin{array}{l}\text { tax evasion, } \\
\text { structural changes }\end{array}$ & \\
& $\begin{array}{l}\text { Intentionality is high } \\
\text { for introducing } \\
\text { property tax }\end{array}$ & $\begin{array}{l}\text { Intentionality is high for the } \\
\text { ETAK system }\end{array}$ & $\begin{array}{l}\text { Intentionality is low for } \\
\text { the ETAK system which } \\
\text { is abandoned. Different } \\
\text { focus and priorities. }\end{array}$ & $\begin{array}{l}\text { Intentionality is high } \\
\text { for reforms, deal with } \\
\text { tax evasion through } \\
\text { the ETAK system }\end{array}$ \\
\hline
\end{tabular}

The contribution of this paper to the IS implementation literature is twofold: firstly, we argue towards the sociomaterial perspective (Orlikowski 2007; Orlikowski and Scott 2008) in the study of IS and control systems implementation (Butler and McGovern, 2012; Sadiq et al., 2012; Papazafeiropoulou and Spanaki, 2017). Such a lens steers away from seeing IS implementation as apolitical (e.g. Davis, 1989; Dwivendi et al, 2017) and argues about the inseparability of social and the technical, the human and non-human, thereby illustrating the dynamics of assemblage formation (Deleuze and Guattari, 1987) unfold over time by using the nuances of 'motivation' and 'intentionality' (Burke, 1969a; 1969b; 2003 DeLanda, 2006; 2011) and their further operationalisation ('passion' and 'desire') (Schandorf and Karatzogianni, 2014). Secondly, we offer an alternative conceptualization to IS implementation through the assemblage and 'performation' (the process of performativity) lens; a successful implementation is linked to when the assemblage is performing as intended. Success is manifested through high motivation and intentionality. The human and non-human agents are motivated and their intention is to work towards the implementation of the system (and in this case the calculation and collection of property tax). Hence, our study extends the study of Yeow and Faraj (2014); our aim was not to find patterns of sociomaterial change, but to study the emergence of the assemblage of the particular system and policy as the outcome of the motivation and intentionality of the human and non-human agents.

\subsection{Implications for policy and practice}

Our paper is informative to public policy makers and top managers. For public policy makers and managers, our study argues that there is a need to attend to the emergent dynamics of both human and non-human entities that constitute the system. Since high levels of motivation and intentionality lead to higher chances of success (i.e. performativity success), it would be important for managers and policy makers to find ways of motivating staff to ensure success whilst ensuring that the appropriate policies and infrastructure are in place or can be secured. Furthermore, our case findings highlight the importance of: (i) securing political consensus for the implementation of tax policies and systems no matter what the political cost may be; (ii) communication between 
policy makers and managers (including project and IT managers) so that decisions taken at a political level are pragmatic and can be translated into guidelines for systems' implementation, and vice-versa; (iii) cultivating a common innovative mindset and a culture prone to change that enables the wide adoption of policies and systems by the public. It is crucial to understand not only the technological aspects, but also the political, cultural, and power aspects of systems and policy implementation. However, these will require significant shift from a top-down implementation approach *that is usually the case) to a bottom-up approach and a significant investment in time, resources, and changes in mindset that cannot be imposed (Papadopoulos et al., 2013; Stamati et al., 2015).

\section{Conclusion}

In this paper we focused on IS implementation in complex settings from a 'sociomaterial' perspective. We adopted the work of Deleuze, Guattari, and Delanda on 'assemblage theory' and Burke's on motive (expressed as 'intentionality' and 'motivation') to study the emergence of technology and policy as an assemblage constituted by human and non-human agents, using a longitudinal qualitative inductive case study of Greece's Yearly Property Tax policy and information system over the period 1997-2015. Therefore, we contribute to the literature on IS implementation drawing on sociomateriality, by explaining the emergence of the system and policy as a sociomaterial assemblage and by using the concepts of motivation and intentionality as an apparatus to explain how assemblages come into being, how they are held together, and how they evolve into new forms. We proposed that high levels of human agents' motivation and non-human agents' intentionality are necessary for the success of the implementation process and the successful performation of the system and policy.

The limitation of this study is based on the qualitative research (Lincoln and Guba, 1985) tenets. In particular, the results cannot be generalised, but can be used to inform theory as we provide an alternative view of a phenomenon and our results need to be judged depending on the plausibility of the reasoning used when analysing the findings and drawing conclusions from our data.

Our arguments could be further developed and extended in the future. In particular, a future study could involve the further study of patterns of sociomaterial change; using, for instance the concepts by Yeow and Faraj (2014) (constituting, counter-performing, calibrating, and stratifying) in conjunction with our proposed nuances to further refine the process of emergence. From a methodological point of view, future studies could further explore the use of measures of motivation and intentionality in order to provide more accurate findings of the different levels (if 
they exist) of motivation and intentionality with regards to the emergence of technology and policy. We therefore intend to provide food for thought to academics and practitioners to further study the emergence and improve the success of policy and technology implementation.

Postscript: The Greek taxation system is altogether operational. Even using a different name for property tax (i.e. ENFIA), taxation is solemnly based on the process and algorithms of ETAK. The ETAK system is consistently maintained, acknowledging the potential and significance of the property tax IS for the stability of the Greek economy and achieving fiscal targets. Based on the latest economic indicators, in 2016, property tax revenues were equal to 3.6B€, reaching almost $0.8 \%$ of the total tax revenue (47B€), exceeding by almost 6 times the contribution of property tax in total tax revenue before the ETAK system (0.14\% in 2008).

\section{References}

Avgerou, C., and McGrath, K. 2007. Power, rationality, and the art of living through socio-technical change MIS Quarterly, 31 (2). 293-315.

Avgerou, C., Ciborra, C., and Land, F. (Eds) 2004. The social study of ICT: innovation, actors and contexts. Oxford University Press, Oxford.

Barad, K. 2003. "Posthumanist Performativity: Toward an Understanding of How Matter Comes to Matter," Signs: Journal of Women in Culture and Society 28(3), 801-831.

Bloomfield, B.P., and Hayes, N. 2009. Power and organizational transformation through technology: hybrids of electronic government. Organization Studies, 30(5), 461-487.

Bryman, A., and Bell, E. 2011. Business Research Methods. New York: Oxford University Press.

Burke, K 1969a, A grammar of motives, University of California Press, Berkeley, CA.

Burke, K 1969b, A rhetoric of motives, University of California Press, Berkeley, CA.

Burke, K 2003, '(Nonsymbolic) motion/(symbolic) action', In WH Rueckert \& A

Butler, T., \& McGovern, D. 2012. A conceptual model and IS framework for the design and adoption of environmental compliance management systems. Information Systems Frontiers, 14(2), 221-235.

Bonadonna (eds.), On Human Nature: A Gathering While Everything Flows 1967-1984, University of California Press, Berkeley, Los Angeles, and London.

Carlile, P. R. 2004. Transferring, translating, and transforming: An integrative framework for managing knowledge across boundaries. Organization Science 15(5), 555-568.

Carlile, P. 2002. A pragmatic view of knowledge and boundaries: Boundary objects in new product development. Organization Science 13, 442-455.

Cecez-Kecmanovic, D., Kautz, K., and Abrahall, R. 2014. Reframing Success and Failure of Information Systems: A Performative Perspective, MIS Quarterly 38(2), 561-588.

Ciborra, C. 2002. The labyrinths of information. Challenging the wisdom of systems. Oxford: Oxford University Press. 
Ciborra, C., and Lanzara, G. F. 1994. Formative contexts and information technology: Understanding the dynamics of innovation in organizations. Accounting, management, and information technologies 4(2), 61-86.

Ciborra, 2005. Interpreting e-government and development. Efficiency, transparency or governance at a distance? Information Technology \& People 18(3), 260-279.

Cordella, A., and Iannacci, F. 2010. Information systems in the public sector: The e-Government enactment framework. Journal of Strategic Information Systems 19(1), 52-66.

Dang, Y.M., Zhang, Y.G., \& Morgan, J. 2017. Integrating switching costs to information systems adoption: An empirical study on learning management systems. Information Systems Frontiers, 19(3), 625-644.

Davis, F. 1989. Perceived Usefulness, Perceived Ease of Use and User Acceptance of Information Technology. MIS Quarterly 13(3), 319-340.

DeLanda, M. 2006. A New Philosophy of Society: Assemblage Theory and Social Complexity. (Continuum, 2006. 2006)

DeLanda, M. 2011. Philosophy and simulation: The emergence of synthetic reason, Continuum, London and New York, NY.

Deleuze, G \& Guattari, F 1987, A thousand plateaus: Capitalism and schizophrenia, trans. B Massumi, Continuum, London and New York, NY.

Doolin, B. and McLeod, L., (2012). Sociomateriality and boundary objects in information systems development. European Journal of Information Systems 21, 1-17.

Dwivendi, Y., Rana, N., Jeyaraj, A., Clement, M. \& Williams, M. (2017). Re-examining the Unified Theory of Acceptance and Use of Technology (UTAUT): Towards a Revised Theoretical Model. Information Systems Frontiers, https://doi.org/10.1007/s10796-017-9774-y

Fosso Wamba, S., Edwards, A. \& Akter, S. Annals of Operations Research (2017). https://doi.org/10.1007/s10479-017-2545-9

Hirschheim, R., and Klein, H.K. 1989. Four paradigms of information systems development. Communications of the ACM 32(10), 1199-1216.

Introna, L. 1997. Management, information and power: A narrative of the involved manager. Macmillan.

Irani, Z., Elliman, T., and Jackson, P. 2007. Electronic transformation of government in the U.K.: a research agenda. European Journal of Information Systems 16, 327-335.

Irani, Z., Love, P.E.D., and Jones, S. 2008. Learning lessons from evaluating eGovernment: Reflective case experiences that support transformational government. Journal of Strategic Information Systems 17(2), 155 -164 .

Jones, M. 2014. A matter of life and death: exploring conceptualizations of sociomateriality in the context of critical care. MIS Quarterly 38(3), 895-925.

Klein, H.K., and Hirschheim, R. 1991. Rationality concepts in information system development methodologies. Accounting, management, and information technologies 1(2), 157-187.

Leonardi, P. 2011. When Flexible Routines Meet Flexible Technologies: Affordance, Constraint, and the Imbrication of Human and Material Agencies. MIS Quarterly 35(1), 147-167.

Leonardi, P. 2012. "Materiality, Sociomateriality, and Socio-Technical Systems: What Do These Terms Mean? How Are They Different?," in Materiality and Organizing: Social Interaction in a Technological World, P. M. Leonardi, B. A. Nardi, and J. Kallinikos (eds.), Oxford, UK: Oxford University Press, pp. 25-48. 
Leonardi, P. 2013. "Theoretical Foundations for the Study of Sociomateriality," Information and Organization (23), pp. 59-76.

Leonardi, P., and Barley, S. 2008. Materiality and change: Challenges to building better theory about technology and organizing. Information and Organization 18(3), 159-176.

Lincoln, Y. S., \& Guba, E. G. (1985). Naturalistic Inquiry. Beverly Hills, CA: Sage Publications Inc.

Njihia, J.M. and Merali, Y. 2013. The Broader Context for ICT4D projects: a Morphogenetic Analysis. MIS Quarterly 37(3), 881-905.

OECD, 2009. OECD Economic Surveys: Greece 2009. Available at: www.oecd.org.

Orlikowski, W. J. 2007. Sociomaterial Practices: Exploring Technology at Work. Organization Studies 28(9), 1435-1448.

Orlikowski, W., and Scott, S.: Sociomateriality: Challenging the Separation of Technology, Work and Organization, Academy of Management Annals, 2008, 2,(1), 433-474

Papadopoulos, T., Stamati, T., Nikolaidou, M., and Anagnostopoulos, D. 2013. From Open Source to Open Innovation Practices: a case in the Greek context in light of the debt crisis. Technological Forecasting and Social Change. 80(6), 1232-1246.

Papazafeiropoulou, A., and Spanaki, K. (2016) Understanding governance, risk and compliance information systems (GRC IS): The experts view. Information Systems Frontiers, 18(6), pp.1251-1263, ISSN: 1387-3326. DOI: $10.1007 /$ s10796-015-9572-3.

Rana, N., Dwivedi, Y., Lal, B., Williams, M. \& Clement, M. (2017). Citizens' adoption of an electronic government system: towards a unified view. Information Systems Frontiers, 19(3), 549-568.

Robey, D., and Markus, M. L. 1984. Rituals in Information System Design. MIS Quarterly 8(1), 5-15.

Rogers, E.M. 2003. Diffusion of innovations (5th ed.). New York: Free Press.

Sadiq, S., Muehlen, M., and Indulska, M. (2012). Governance, risk and compliance: applications in information systems (editorial). Information Systems Frontiers, 14, 123-124.

Schandorf, M., and Karatzogianni, A. 2016. Agency in Posthuman IR: Solving the Problem of Technosocially Mediated Agency'. In Posthuman Dialogues in International Relations, edited by E. Cudworth, S. Hobden and E. Kavalski, Ashgate.

Scott, S.V., and Orlikowski, W. 2014. Entanglements in Practice: Performing Anonymity Through Social Media. MIS Quarterly 38(3), 873-893.

Silverman, D. (2001). Interpreting Qualitative Data: Methods for Analysing Talk, Text and Interaction (2nd ed ). London/Thousand Oaks, New Delhi: Sage.

Stamati, T., Papadopoulos, T., and Anagnostopoulos, D. 2015. Social media for openness and accountability in the public sector: Cases in the Greek context. Government Information Quarterly 32(1), 12 29.

Venkatesh, V., Morris, M., Davis, G., and Davis, F. 2003). User acceptance of information technology: toward a unified view. MIS Quarterly 27, 425-478

Venters, W., Oborn, E., and Barrett, M. 2014. A Trichordal temporal approach to digital coordination: the sociomaterial mangling of the CERN grid. MIS Quarterly 38(3), 927-949.

Walsham, G. 2001. Making a World of Difference: It in a Global Context. John Wiley \& Sons, Inc. New York, NY, USA. 
Yeow, A., and Faraj, S. 2014. Technology and Sociomaterial Performation. Information Systems and Global Assemblages. (Re)Configuring Actors, Artefacts, Organizations. Volume 446 of the series IFIP Advances in Information and Communication Technology, pp 48-65

Yin, R. 2003. Case Study Research: Design and Methods. Sage Publications. 